\title{
KERAGAAN PRODUKSI, KETERSEDIAAN BERAS, DAN TRANSFORMASI LAHAN PADI INDONESIA
}

\author{
Apri Andani \\ Jurusan Sosial Ekonomi Pertanian Fakultas Pertanian Universitas Bengkulu
}

\begin{abstract}
The provisions of food in order to fulfill the requirement for humankind could be followed through the implementation of the process of agricultural production. However, the food requirement could only be fulfilled self-sufficiently if food supplies were higher than the total consumption. The trend of the Indonesian rice production rises the problem that immediately must be overcome. This was caused by increasing consumption continuously resulting from the increase in population growth. Besides that, the other problems are rice field transformation, from rice field to industrial and residential area.
\end{abstract}

Key words: production, land transformation, rice

\section{PENDAHULUAN}

Pangan merupakan kebutuhan manusia mendasar yang pemenuhannya menjadi hak bagi setiap orang. Oleh karena itu, ketersediaan atas pangan menjadi sangat penting. Penyediaan pangan demi memenuhi kebutuhan manusia tersebut dapat ditempuh melalui penyelenggaraan proses produksi. Namun, kebutuhan pangan hanya akan dapat terpenuhi jika pasokan pangan lebih tinggi dari konsumsi total. Jika hasil produksi dalam negeri tidak mampu memenuhi kebutuhan pangan, maka mendatangkan pangan dari negara lain menjadi kewajiban demi terpenuhinya kebutuhan pangan nasional. Salah satu sumber pangan yang saat ini menjadi makanan pokok sebagian besar penduduk Indonesia adalah beras.

Data perberasan FAO tahun 2004 dalam Darwanto dan Prima (2007) mengemukakan bahwa dalam empat dekade terakhir produksi beras nasional telah mampu memenuhi sekitar $97 \%$ dari total pasokan yang dibutuhkan setiap tahun. Pasokan beras tertinggi dicapai pada periode 1981-1990 yang mencapai 101\% dari total pasokan per tahun (masa swasembada). Namun 
kemudian menurun terus hingga pada tiga tahun terakhir mencapai rata-rata $94 \%$ dari total pasokan per tahun.

Penelitian Darwanto dan Prima (2007) menyebutkan bahwa sekitar 89\% dari pasokan beras nasional digunakan untuk memenuhi kebutuhan konsumsi beras nasional. Lebih lanjut disebutkan bahwa tingkat konsumsi beras untuk pangan (food) mencapai 121,6 kg per kapita. Tingkat konsumsi beras untuk pangan tersebut pada dasarnya telah dapat dipenuhi dari produksi domestik yang mencapai $107,5 \%$ dari kebutuhan konsumsi beras untuk pangan skala nasional. Namun demikian impor beras masih dilakukan untuk memenuhi kebutuhan nasional lainnya selain pangan dan untuk cadangan beras pemerintah dengan jumlah rata-rata per tahun mencapai sekitar 1.043.140 ton atau sekitar 4,7\% dari pasokan nasional (Darwanto dan Prima 2007). Hal ini menunjukkan bahwa kesetimbangan neraca perberasan nasional masih ditopang oleh impor walaupun dengan tingkat/persentase pemenuhan pasokan domestik yang cenderung menurun selama empat tahun terakhir (2002-2005), seperti terlihat pada tabel berikut.

Tabel 1. Produksi, Ekspor, Impor, dan Rasio Ketergantungan Impor Beras Tahun 2000-2005 (000 Ton).

\begin{tabular}{ccccc}
\hline Tahun & Produksi*) & Impor & Ekspor & $\begin{array}{c}\text { Rasio Ketergantungan } \\
\text { Impor (\%) }\end{array}$ \\
\hline 2000 & 30.045 & 1.354 & 1 & 4,7 \\
2001 & 29.229 & 637 & 4 & 2,2 \\
2002 & 29.431 & 1.786 & 4 & 6,5 \\
2003 & 29.794 & 1.425 & 0,7 & 5,0 \\
2004 & 30.897 & 236 & 2 & 0,8 \\
$\left.2005^{\star *}\right)$ & 30.905 & 189 & 43 & 0,6 \\
\hline
\end{tabular}

Sumber: Data BPS dalam Neraca Bahan Makanan Indonesia 2006, diolah 2008.

Ket:erangan $\left.\quad:{ }^{*}\right)$ Setelah dikurangi penggunaan pakan, bibit, tercecer pada tingkat gabah ${ }^{* *}$ ) Data sementara

Dari data BPS dalam Neraca Bahan Makanan Indonesia 2006 tersebut dapat dilihat bahwa volume impor beras, selama kurun waktu 2000-2005 berfluktuasi dengan kecenderungan menurun. Hal ini dikarenakan produksi beras domestik mengalami kenaikan, meskipun secara 
perlahan dari tahun 2001 sampai 2004, dan diperkirakan terus meningkat sampai tahun 2005. Rata-rata rasio ketergantungan impor beras nasional selama kurun waktu tersebut masih berada dibawah $10 \%$, dengan kisaran antara $0,6 \%$ pada tahun 2005 sampai $6,5 \%$ pada tahun 2002 dengan jumlah impor beras mencapai 1,7 juta ton lebih. Rasio ketergantungan impor merupakan hasil dari perbandingan antara produksi domestik dengan impor beras. Dengan adanya variabel impor dalam nerasa perberasan nasional, maka bisa dikatakan bahwa kemampuan petani domestik dalam memproduksi beras masih lemah, karena masih membutuhkan beras yang berasal dari impor untuk memenuhi kebutuhan beras nasional. Lemahnya pasokan beras domestik disebabkan oleh pertumbuhan faktor penentu besarnya produksi beras nasional yang mengalami kecenderungan menurun dari tahun ke tahun. Faktor tersebut adalah luas lahan panen (harvested area) padi nasional. Selang antara tahun 1999-2005 tercatat dalam data BPS (2006) bahwa telah terjadi pengurangan luas lahan panen padi sebesar 124.204 hektar.

\section{PERKEMBANGAN LUAS LAHAN PANEN PADI NASIONAL}

Lahan merupakan salah satu faktor produksi paling penting dalam mendukung upaya peningkatan produksi padi. Disamping kandungan unsur hara, luas areal tanaman padi juga sangat berpengaruh terhadap produksi yang akan dihasilkan. Logika berfikirnya semakin luas areal yang ditanami, maka akan semakin tinggi pula produksi yang dihasilkan. Namun banyak hal yang menjadi kendala ketika padi sudah berada di lahan, misalnya serangan hama serta bencana alam, seperti banjir yang membuat tanaman padi gagal dipanen.

Dengan semakin berkembangnya teknologi dalam bidang pertanian, serangan hama dapat sedikit diatasi dengan dihasilkannya benih-benih unggul yang resisten terhadap serangan hama maupun penyakit. Disamping itu, perbaikan benih padi ternyata mampu menghasilkan jauh lebih banyak dari benih biasa. Oleh karena itu persoalan keterbatasan lahan, untuk saat ini, menjadi tidak begitu signifikan pengaruhnya terhadap perkembangan produksi padi. Meskipun demikian 
bukan berarti persoalan lahan menjadi masalah yang tidak harus segera diselesaikan. Lambat laun, berkurangnya lahan akibat konversi akan semakin tinggi seiring bertambahnya jumlah penduduk. Jika dilihat dari tabel 6 , perkembangan luas lahan panen padi nasional dari tahun 20032007 selalu mengalami pertumbuhan yang negatif. Berdasarkan survey BPS, hal ini disebabkan oleh dua faktor penting, yaitu luas puso tanaman serta konversi lahan.

Tabel 6. Perkembangan Luas Lahan Panen Padi Nasional 2003-2005 (ribu ha)

\begin{tabular}{lrrrrrc}
\hline Jenis Padi & $\mathbf{2 0 0 3}$ & $\mathbf{2 0 0 4}$ & $\mathbf{2 0 0 5}$ & $\left.\mathbf{2 0 0 6} \mathbf{*}^{\boldsymbol{*}}\right)$ & $\mathbf{2 0 0 7 ^ { * * } )}$ & $\begin{array}{c}\text { Pertumbuhan (\%) } \\
\mathbf{2 0 0 6 - 2 0 0 7}\end{array}$ \\
\hline - Padi & 11.488 & 11.922 & 11.839 & 11.780 & 11.426 & $-3,01$ \\
- Padi Sawah & 10.365 & 10.799 & 10.733 & 10.709 & 10.395 & $-2,94$ \\
- Padi Ladang & 1.094 & 1.123 & 1.105 & 1.071 & 1.031 & $-3,71$ \\
\hline
\end{tabular}

Sumber: Badan Pusat Statistik dan Dirjen Tanaman Pangan (Deptan)

Ket : *) Angka Sementara

**) Angka Prakiraan I

Tabel 6 menggambarkan kondisi luas lahan panen padi nasional yang setiap tahun dari tahun 2003 sampai 2007 selalu mengalami penyempitan. Pada tahun 2003 produksi padi mencapai luas areal 11,5 juta hektar dengan produktivitas padi mencapai 4,5 ton per hektar. Sementara pada tahun 2004 terjadi peningkatan areal tanaman padi seluas 434.000 hektar menjadi 11,9 juta hektar. Pada tahun berikutnya, yaitu tahun 2005, terjadi penurunan luas lahan panen seluas 83.000 hektar. Pada tahun 2005, terjadi puso tanaman padi seluas 212.805 hektar. Diramalkan luas lahan panen padi akan terus menurun sampai pada level hampir setengah juga hektar pada tahun 2007. Pertumbuhan negatif ini lebih disebabkan oleh bencana alam banjir dan kemarau panjang di beberapa wilayah di Indonesia, khususnya pulau Jawa, serta konversi lahan manjadi lahan non-pertanian. Sedangkan serangan hama beberapa tahun belakangan ini jarang menjadi penyebab utama gagal panen tanaman padi petani.

\section{PERKEMBANGAN PRODUKSI BERAS NASIONAL}

Perkembangan produksi padi, berdasarkan data statistik nasional, apabila dibagi 10 tahunan, 1950-1959 naik 3,7 \% per tahun, 1960-1969 naik 4,6 \% per tahun, 1970-1979 naik 3,6 \% 
per tahun, 1980-1990 naik 4,3 \% per tahun, 1991-2000 naik 1,4 \% per tahun dan dari tahun 20032006 naik hanya 2,3\% per tahun. Jika dilihat persentase pertumbuhannya, terjadi gejala leveling off produksi padi sejak tahun 1992. Kenaikan hanya mencapai rata-rata 1,4\%. Hal ini antara lain disebabkan terkurasnya tingkat kesuburan tanah yang terus-menerus ditanami pupuk anorgnaik disamping terjadinya alih fungsi lahan sawah selama beberapa tahun ini. Berkurangnya lahan memang tidak secara signifikan mengurangi produksi nasional. Hal ini dikarenakan produktivitas padi per hektar juga mengalami kenaikan dari rata-rata 4,5 ton/hektar pada tahun 2003 menjadi 4,8 ton/hektar pada tahun 2006. Tabel 7 menunjukkan perkembangan produksi padi nasional dari tahun 2003-2005.

Tabel 7. Perkembangan Produksi Padi Nasional Tahun 2003 - 2005 (ribu ton)

\begin{tabular}{lrrrc}
\hline \multicolumn{1}{c}{ Pulau } & $\mathbf{2 0 0 3}$ & $\mathbf{2 0 0 4}$ & $\mathbf{2 0 0 5}$ & Pertumbuhan (\%) \\
\hline Sumatera & 12.136 & 12.666 & 12.675 & 2,50 \\
Jawa & 28.168 & 29.636 & 29.764 & 2,14 \\
Bali \& Jawa & 2.725 & 2.807 & 2.616 & 1.27 \\
Kalimantan & 3.358 & 3.657 & 3.614 & 5,56 \\
Sulawesi & 5.602 & 5.171 & 5.301 & 1,36 \\
Maluku \& Papua & 149 & 151 & 181 & 9,31 \\
\hline Indonesia & 52.138 & 54.088 & 54.151 & 2,30 \\
\hline
\end{tabular}

Sumber: Badan Pusat Statistik (2005), diolah 2008.

Tabel 7 menunjukkan bahwa Pulau Jawa masih merupakan penyumbang pasokan padi nasional terbesar dengan produksi sebesar 28 juta ton pada tahun 2003 dan meningkat menjadi 29,7 juta ton pada tahun 2005 , atau mengalami rata-rata pertambahan sebesar $2,14 \%$ setiap tahun. Peringkat kedua penghasil padi nasional adalah pulau Sumatera. Pulau ini mampu memasok kebutuhan nasional rata-rata sebesar 12 juta ton dengan rata-rata pertumbuhan 2,5\% setiap tahun. Disamping kedua pulau tersebut, ada dua pulau besar lagi yang bisa dijadikan daerah potensial penghasil padi, yaitu Kalimantan dan Papua. Kedua pulau ini masih memiliki lahan kosong yang cukup luas untuk dikembangkan sebagai daerah sentra produksi padi. Dilihat dari persentase pertambahan, Kalimantan 5,56\% dan Papua 9,31\%, kedua pulau ini menjadi 
sangat potensial untuk dijadikan daerah sasaran baru perluasan areal tanaman padi guna mengatasi masalah kerawanan pangan saat ini.

Namun keberhasilan sektor pertanian padi nampaknya saat ini masih dipandang sebagai keberhasilan jumlah produksi, sehingga prioritas kebijakan pemerintah masih berpatokan pada angka-angka pencapaian target produksi. Fluktuasi produksi yang menyertai angka pencapaian target produksi beras, membuktikan bahwa sektor pertanian padi masih sangat rentan terhadap perubahan alam dan kebijakan pemerintah. Terlepas dari masalah itu, penanganan panen dan pascapanen ternyata memiliki kontribusi yang cukup besar dalam mengamankan produksi beras nasional. BPS menyebutkan kehilangan hasil panen dan pascapanen akibat ketidaksempurnaan penanganan mencapai $20,51 \%$, dimana kehilangan pada saat pemanenan sebesar $9,52 \%$, perontokan $4,78 \%$, pengeringan $2,13 \%$, dan penggilingan 2,19\%. Jika angka ini dikonversikan dengan produksi padi nasional yang mencapai 57 juta ton (ARAM III 2007), maka akan setara dengan kehilangan Rp 26,9 triliun (didasarkan pada harga pembelian pemerintah menurut Inpres No. 3 Tahun 2007 tentang kebijakan perberasan, dengan HPP rata-rata GKP dan GKG sebesar Rp 2.305,-). Kehilangan saat panen dan pascapanen ini pula yang mengakibatkan gap produksi padi dengan beras menjadi cukup besar pada tahun 2005, yaitu dari 54,1 juta ton padi hanya menjadi 31,7 juta ton beras (Tabel 8). Padahal faktor konversi padi ke beras ditoleransi pada level $34 \%$, kenyataannya mencapai $41,4 \%$. Artinya ada kehilangan sebesar $7,4 \%$ dari total produksi padi nasional atau sekitar 3,8 juta ton padi.

Tabel 8. Perkembangan Produksi dan Ketersediaan Beras Nasional

\begin{tabular}{ccrccc}
\hline Tahun & $\begin{array}{c}\text { Produksi Beras } \\
\text { (000 ton) }\end{array}$ & $\begin{array}{c}\text { Impor } \\
\text { (000 ton) }\end{array}$ & $\begin{array}{c}\text { Ketersediaan } \\
\text { Beras (000 ton) }\end{array}$ & $\begin{array}{c}\text { Penduduk } \\
\text { (juta) }\end{array}$ & $\begin{array}{c}\text { Ketersediaan } \\
\text { Beras (kg/kapita) }\end{array}$ \\
\hline 2003 & 30.546 & 1.437 & 31.983 & 223,45 & 143,13 \\
2004 & 31.688 & 246 & 31.934 & 227,54 & 140,35 \\
2005 & 31.725 & 195 & 31.920 & 231.71 & 137,76 \\
\hline
\end{tabular}

Sumber: Badan Pusat Statistik, 2007, diolah 2008. 
Tabel 8 juga menunjukkan seberapa besar penyediaan beras perkapita setiap tahun dari tahun 2003 sampai 2005 (angka riil). Dapat dilihat bahwa ketersediaan beras dari tahun ke tahun semakin menurun. Pada tahun 2003 produksi beras nasional mampu menjamin tersedianya beras sebesar 143,13 kg/kapita, namun kemudian turun menjadi 140,35 kg/kapita pada satu tahun berikutnya. Bahkan pada tahun 2005 ketersediaan beras mencapai level 137,76 kg/kapita, atau turun sebesar 5,37 kg/kapita. Padahal pasokan beras nasional sudah dibantu dengan adanya beras impor. Ini berarti peningkatan produksi belum mampu mengimbangi tingginya pertambahan jumlah penduduk.

\section{PERKEMBANGAN KONSUMSI BERAS NASIONAL}

Keragaan konsumsi beras secara nasional yang dibagi atas wilayah kota dan desa memperlihatkan kecenderungan menurun dari tahun ke tahun antara tahun 1999 sampai 2005. Konsumsi beras rata-rata nasional pada tahun 1999 adalah 116,49 kg/kapita kemudian turun menjadi 105,23 kg/kapita pada tahun 2005 (Tabel 9).

Tabel 9. Perkembangan Konsumsi Beras Nasional Tahun 1999-2005 (kg/kapita)

\begin{tabular}{lccccr}
\hline \multicolumn{1}{c}{ Wilayah } & $\mathbf{1 9 9 9}$ & $\mathbf{2 0 0 2}$ & $\mathbf{2 0 0 3}$ & $\mathbf{2 0 0 4}$ & $\mathbf{2 0 0 5}$ \\
\hline Kota & 112,73 & 111,14 & 113,13 & 100,24 & 97,03 \\
Desa & 118,91 & 118,76 & 119,45 & 112,10 & 112,44 \\
\hline Kota + Desa & 116,49 & 115,48 & 109,71 & 107,00 & 105,23 \\
\hline
\end{tabular}

Sumber: Susenas 1999-2005: BPS diolah Pusat KKP Deptan, diolah 2008.

Penurunan signifikan terjadi pada konsumsi masyarakat kota. Pada tahun 1999 konsumsi beras masyarakat kota masih berada pada level 112,73 kg/kapita, namun turun sebesar15 kg/kapita 6 tahun berikutnya menjadi hanya $97,03 \mathrm{~kg} / \mathrm{kapita}$ pada tahun 2005. Hal ini dikarenakan munculnya jenis-jenis hidangan makanan yang menjadikan nasi bukan sebagai makanan utama, sehingga lebih bervariasi, seperti makanan Jepang dengan ikan sebagai menu utamanya, makanan Cina dengan mi sebagai menu pokok, serta makanan Eropa yang menghidangkan roti dan sayuran sebagai makanan khasnya. Ini didukung oleh semakin membaiknya tingkat 
kesejahteraan mereka. Tabel 10 menunjukkan hubungan antara tingkat pengeluaran per kapita dengan jumlah konsumsi beras per kapita yang dibedakan antara masyarakat perkotaan dengan pedesaan.

Tabel 10. Rata-Rata Konsumsi per Kapita Seminggu Menurut Golongan Pengeluaran per Kapita Sebulan Tahun 1999

\begin{tabular}{cccc}
\hline \multirow{2}{*}{$\begin{array}{c}\text { Golongan Pengeluaran per } \\
\text { kapita per bulan (Rp) }\end{array}$} & \multicolumn{3}{c}{ Konsumsi beras per kapita per minggu (Kg) } \\
\cline { 2 - 4 } & Pedesaan & Pekotaan & Nasional \\
\hline$<40.000$ & 0,994 & 1,468 & 1,021 \\
$40.000-59.999$ & 1,554 & 1,707 & 1,576 \\
$60.000-79.999$ & 1,915 & 1,768 & 1,885 \\
$80.000-99.999$ & 2,215 & 1,801 & 2,036 \\
$100.000-149.999$ & 2,323 & 1,848 & 2,139 \\
$150.000-199.999$ & 2,429 & 1,834 & 2,101 \\
$200.000-299.999$ & 2,409 & 1,775 & 1,961 \\
$300.000-499.999$ & 2,266 & 1,691 & 1,874 \\
$>500.000$ & 2,132 & 1,592 & 1,648 \\
\hline
\end{tabular}

Sumber: Susenas 1999, diolah Badan BKP-Deptan.

Tingkat pengeluaran per kapita per bulan berpengaruh terhadap besarnya konsumsi beras per kapita per minggu. Pada tingkat nasional rata-rata konsumsi beras per kapita meningkat pada golongan pengeluaran di bawah Rp 150.000,- per bulan, dan baru mengalami penurunan konsumsi beras pada golongan pengeluaran di atas Rp 150.000,-. Semakin tinggi tingkat pengeluaran per kapita, maka dipastikan bahwa tingkat pendapatan juga tinggi, dan konsumsi terhadap beras semakin berkurang. Simatupang dan Mewa (1997) mengatakan bahwa diversifikasi pangan merupakan mekanisme untuk memenuhi kebutuhan zat gizi. Salah satu faktor utama penentu diversifikasi pangan adalah tingkat pendapatan. Dengan demikian, upaya untuk memenuhi kebutuhan zat gizi melalui diversifikasi pangan akan lebih berhasil apabila pendapatan keluarga cukup tinggi atau meningkat. Dapat disimpulkan bahwa semakin tinggi tingkat pengeluaran per kapita, maka akan semakin bervariasi pula makanan yang akan dikonsumsi. Sehingga mengakibatkan berkurangnya konsumsi terhadap beras. Kondisi ini terlihat begitu signifikan pada masyarakat yang terletak di wilayah perkotaan. 
Berbeda halnya dengan konsumsi di wilayah pedesaan yang mengalami penurunan namun tidak tajam. Salah satu penyebabnya adalah karena jauh dari variasi makanan. Selain itu, nasi masih menjadi idola dalam pemenuhan energi bagi masyarakat di wilayah ini, sehingga hanya terjadi penurunan sebesar 6,47 kg/kapita sepanjang tahun 1999-2005 (Tabel 9). Selain karena minimnya penyediaan makanan yang beragam, rendahnya tingkat kesejahteraan menjadi faktor utama penyebab kurangnya penganekaragaman konsumsi energi. Nasi menjadi menu favorit karena dianggap paling murah dan paling mudah didapat.

Dari konsumsi beras saja sebenarnya dapat dilihat ketimpangan yang terjadi antara masyarakat perkotaan dan pedesaan. Dengan tingkat kesejahteraan yang jauh lebih baik, masyarakat kota tidak lagi menggantungkan konsumsi energinya pada beras, sehingga ketika tidak ada beras, mereka sudah siap menggantinya dengan makanan lain. Kondisi sebaliknya terjadi pada masyarakat pedesaan yang takut kehilangan beras. Padahal masih ada sumber energi lain, misalnya singkong.

\section{KONVERSI LAHAN}

Kepulauan Indonesia yang berjumlah lebih dari 13.600 pulau menjembatani bentangan jarak sekitar 5000 km antara benua Asia dan Australia, dari ujung utara Sumatera sampai ke Papua Barat. Sistem kepulauan ini sebagian besar disusun oleh sistem pegunungan Sunda -salah satu jalur pegunungan darat dan bawah air terbesar di dunia. Sepanjang rangkaian pegunungan ini, dua busur pegunungan membujur sejajar, busur dalamnya bersifat vulkanik sedang busur luarnya tidak. Pulau Jawa memiliki berbagai jenis tanah, dan yang berasal dari busur vulkanik yang sangat subur. Dataran rendah pulau-pulau selain Jawa terdiri atas tanah aluvial dan dataran berawa.

Secara fisiografis hampir sebagian besar pulau-pulau utama Indonesia memiliki gunung berapi. Kondisi ini memungkinkan beberapa bagian wilayah Indonesia memiliki corak tanah yang 
relatif kaya unsur hara alami. Hal ini dapat dilihat dari hampir semua lokasi di Pulau Jawa, kecuali di bagian sisi selatannya. Sebagian besar tanah di wilayah ini didominasi oleh tanah podsolik/latosol/ultisol/regosol, dengan $\mathrm{pH}$ sekitar 4-5, kandungan c-organik rendah, memiliki kandungan liat/pasir tinggi dan miskin hara (Syahbuddin dan Manabu, 2005). Hasil penelitian CSAR (Center for Soil Agroclimate Research) pada tahun 1997, menyimpulkan bahwa tipe jenis tanah tersebut juga tersebar hampir di seluruh pelosok sebagian besar pulau Sumatera, Kalimantan, dan Sulawesi. Bahkan untuk tanah Podsolik Merah Kuning (PMK) saja sebarannya mencapai 47,5 juta ha atau $25 \%$ di seluruh Indonesia.

Namun hasil penelitian Mulyani et al. (2001) dalam Syahbuddin (2002) menunjukkan sesuatu yang memberi harapan cerah. Hasil penelitian tersebut menyebutkan bahwa untuk Propinsi Lampung saja terdapat sekitar 320.000 ha lahan kering yang potensial untuk pengembangan padi sawah dan palawija. Luasan ini 1,5 lebih besar dari luas lahan sawah potensial di sepanjang jalur pantura Jawa Barat. Sehingga total luasan areal potensial untuk perluasan areal baru tanaman padi yang ada di seluruh penjuru nusantara akan mencapai 3-5 juta ha. Luasan ini tentunya akan menghasilkan produk pertanian, seperti padi dan palawija, serta mendatangkan manfaat yang sangat besar jika dikelola dengan baik serta didukung oleh kontinuitas ketersediaan air. Lebih lanjut hasil penelitian memperkirakan dengan lahan sedemikian luas, maka akan diperoleh minimal 6-10 juta ton padi dan sekitar 3-5 juta ton palawija dalam satu kali musim tanam. Ditambah lagi jika di antara luasan areal tersebut ada yang dapat ditanami 2 kali dalam setahun. Ditinjau dari sisi luas arealnya, lahan kering memberikan harapan besar untuk dikembangkan.

Tata guna lahan di Indonesia sebagian besar masih didominasi oleh hutan belantara dan semak belukar, yaitu sebesar $63 \%$ dari total luas daratan Indonesia. Sekitar 8,5\% merupakan 
lahan perkebunan, 7,8\% lahan kering, 13\% lahan digunakan untuk pemukiman dan industri, tegalan, dan ilalang, serta hanya 4,5\% lahan sawah atau sekitar 11,6 juta hektar (BPS 2007).

Lahan pertanian produktif, khususnya sawah, yang selama ini diusahakan petani lambat laun mulai terkonversi menjadi areal pemukiman dan industri. Meskipun pemerintah mulai menggalakkan pembukaan areal persawahan baru, namun kondisi ini akan mengancam ketahanan pangan nasional di masa yang akan datang. Bahkan selama sepuluh tahun dari tahun 1992 sampai 2002 tercatat konversi lahan sawah rata-rata per tahun seluas 110.000 hektar. Bahkan di Pulau Jawa, dengan sebagian besar wilayahnya adalah sentra produksi padi, sebagian besar atau sekitar $58 \%$ konversi lahan terjadi dari lahan sawah ke permukiman. Berikut adalah luas konversi yang terjadi pada lahan sawah di beberapa pulau utama di Indonesia sejak tahun 1999 sampai 2003. Selama kurun waktu tersebut hampir satu juta hektar lahan sawah beralih fungsi ke non pertanian.

Tabel 3. Luas Konversi Lahan Sawah di Indonesia antara Tahun 1999-2003 (ha)

\begin{tabular}{lcc}
\hline \multicolumn{1}{c}{ Pulau } & Lahan Baku Sawah 1999 & Pengurangan Sawah \\
\hline - Sumatera & 2.173 .117 & 235.384 \\
- Bali dan NTT & 597.873 & 13.789 \\
- Kalimantan & 1.066 .011 & 105.030 \\
- Sulawesi, Maluku, dan Papua & 893.974 & 35.803 \\
- Luar Jawa & 4.730 .975 & 396.010 \\
- Jawa & 3.375 .581 & 167.150 \\
\hline Indonesia & 12.837 .531 & 953.166 \\
\hline
\end{tabular}

Sumber: Badan Pusat Statistik (BPS), 2004, diolah 2008.

\section{PENUTUP}

Lemahnya pasokan beras yang berasal dari produksi domestik bukan berarti produksi beras nasional mengalami penurunan. Produksi beras nasional tetap naik meskipun kenaikannya tidak signifikan dari tahun ke tahun. Hal ini lebih dikarenakan tingginya alih fungsi lahan dari lahan sawah menjadi areal industri dan pemukiman. Jika dibiarkan terus menerus, kondisi ini akan 
menekan ketersediaan pangan nasional karena kenaikan produksi pangan, khusus beras, tidak seimbang dibanding dengan kenaikan jumlah penduduk yang menyerupai deret ukur.

Ketersediaan pangan khusus beras dari sisi impor mempunyai resiko yang sangat besar karena disamping makin terbatasnya devisa yang dimiliki juga adanya ketidakpastian dari segi jumlah dan harga di pasar internasional. Berdasarkan perkembangan produksi, impor, dan ekspor komoditas pangan khusus beras, maka dapat diperkirakan kemampuan cadangan pangan dan ketersediaan pangan yang implikasinya berpengaruh terhadap ketahanan pangan nasional, dan wilayah.

Berbasis pada kebijakan pembangunan sektor pertanian dan ketahanan pangan, maka pemecahan masalah di subsektor pangan, khususnya beras, dapat ditempuh melalui pengembangan tanaman pangan dan konsumsi pangan lokal serta penganekaragaman konsumsi pangan yang mengarah pada perbaikan konsumsi pangan oleh masyarakat, baik dari segi jumlah maupun kualitas makanan termasuk keragaman dalam rangka mewujudkan konsumsi pangan dengan gizi seimbang.

Hal ini perlu segera dilaksanakan dengan tujuan mengurangi pangan impor dan ketergantungan pada beras. Dengan terpenuhinya konsumsi pangan yang beragam dari waktu ke waktu pada masa yang akan datang, maka masyarakat dapat hidup sehat dan mampu melaksanakan aktivitasnya sehari-hari secara produktif, sehingga diharapkan mampu meningkatkan kesejahteraan.

\section{DAFTAR PUSTAKA}

[Deptan]. 2006. Neraca Bahan Makanan Indonesia 2004-2005. Badan Ketahanan Pangan Departemen Pertanian. Jakarta.

[BPS]. 2006. Perkembangan Konsumsi Pangan Penduduk Indonesia 1993-2005. Susenas BPS. Jakarta.

2007. Rapat Pembahasan Angka Ramalan III (ARAM III) 2007 Produksi Padi dan Palawija. Direktorat Statistik Pertanian. BPS. Jakarta. 
[Center for Soil and Agroclimate Research]. 1997. Statistik Sumberdaya Lahan/Tanah Indonesia. Pusat Penelitian Tanah dan Agroklimat, Badan Litbang Departemen Pertanian. Jakarta.

Darwanto H. D dan Prima Y. R. 2007, Kesejanteraan Petani dan Peningkatan Ketersediaan Pangan: Sebuah Dilemma. Jurnal Ekonomi Rakyat. www.jurnalekonomirakyat.com. (23 Desember 2007)

Simatupang P dan Mewa A. 1997. Hubungan Antara Pendapatan Rumah Tangga dan Pergeseran Preferensi Terhadap Pangan. Jurnal Pangan (33). 20-29. Jakarta.

Syahbuddin H dan Manabu D.Y. 2005. Water Depletion from Four Soil Layers in the Tropic. Graduate School of Science and Technology. Kobe University. 15 pages. Kobe University Press.

Syahbuddin H. 2002. Ketersediaan Air dan Pola Tanam pada Lahan Kering berdasarkan Peluang Kejadian Iklim di Propinsi Lampung. 24 hal. Indonesia Agro-climate and Hydrology Research Institute. Bogor. 